\section{SOI: $1.1 / \mathrm{TAS} \quad$ DOI: $10.15863 / \mathrm{TAS}$ \\ International Scientific Journal Theoretical \& Applied Science}

\author{
p-ISSN: 2308-4944 (print) e-ISSN: 2409-0085 (online) \\ Year: $2016 \quad$ Issue: 2 Volume: 34
}

Published: 29.02.2016 $\underline{\text { http://T-Science.org }}$

\author{
Amelia Girly L. Aranas \\ BPA., MPA., DPA., Ph.D. \\ College of Arts and Sciences, Main Campu, \\ Cebu Technological University \\ Cebu City, Philippines \\ dr.glaranas@yahoo.com \\ (0939-848-1122)
}

SECTION 19. Management. Marketing. Public administration.

\title{
POLICY FOR IMPROVING COMPETITIVENESS OF THE GOVERNMENT WORKER: ITS PERFORMANCE
}

\begin{abstract}
The need to establish an effective system that accurately evaluates the performance of its workers for the purpose of determining tenure, transfers or promotions, and appropriate incentives is of absolute urgency. The purpose of this study is to determine the competitiveness of the government permanent workers in the College of Arts and Sciences, Cebu Technological University-Main Campus, Cebu City for the Academic Year 2010-2012. Specifically: to examine the performance appraisal report of the faculty: as to teaching competencies; professionalism; and services to the college and the community; supervisor: as to professional competence; supervisory competence; leadership skills; and personal characteristics; students/clientele: as to management; and performance. The descriptive-qualitative fish-bowl method was utilized in this study. Our study indicates that based on the implementation, the Cebu Technological University-Main Campus Particularly College of Arts and Sciences, Very Satisfactorily Complied the variables indicated as success indicator of the Performance Appraisal Report (PAR) for the Academic Year 2010-2012.

Key words: teaching competencies; professionalism; professional competence; supervisory competence; leadership skills; and personal characteristics.

Language: English

Citation: Aranas AGL (2016) POLICY FOR IMPROVING COMPETITIVENESS OF THE GOVERNMENT WORKER: ITS PERFORMANCE. ISJ Theoretical \& Applied Science, 02 (34): 54-57.

Soi: http://s-o-i.org/1.1/TAS-02-34-9 Doi: crossef http://dx.doi.org/10.15863/TAS.2016.02.34.9
\end{abstract}

\section{INTRODUCTION}

Achievement of objectives and good returns on investment could only be attained if human resources aspects of the human enterprise are properly developed through training and manpower development [1]. An organization's future prosperity depends not only upon providing a product which is competitive neither in price, quality and quantity nor of simply increasing the range of products produced. If the organization has people of vision, energy and experience to direct the force and facilities, then the other requirement for success should follow. The development of the Performance Management System (PMS) was initiated in 2003 by a reassessment of the existing Performance Evaluation System (PES) and development of a new tool/instrument that will establish a culture of performance and accountability in the bureaucracy. The Performance objectively links employee performance vis-à-vis its Organizational Vision, Mission, and Strategic Goals. The PMS employs the concept of performance contracting public servants to produce tangible results by "making a difference" instead of "just keeping busy", demand accountability and consequently, results increased accountability by performing the mandate of the organization, need to correct the notion that a permanent appointment guarantees security of tenure [2].

Management exists for the sake of the institution's results. It has to start with the intended results and has to organize the resources of the institution to attain [3]. Goal is a desired future state that the organization attempts to realize [4]. Hence, the call for the Civil Service Commission (CSC), as the central personnel agency of the government, to revisit and, as necessary, re-invent the performance management system of the bureaucracy.

\section{MATERIALS AND METHODS}

The descriptive-qualitative fish-bowl method was utilized in this study. The purpose of this study is to determine the performance management system in the College of Arts and Sciences, Cebu 
Technological University-Main Campus, Cebu City for the Academic Year 2010-2012. The respondents/informants of the study were department heads, faculty and students to examine the performance appraisal report of the faculty: as to teaching competencies; professionalism; and services to the college and the community; supervisor: as to professional competence; supervisory competence; leadership skills; and personal characteristics; students/clientele: as to management; and performance.

\section{RESULTS AND DISCUSSION}

The Civil Service Commission's Performance Management System is a system which would meaningfully and objectively link employees' performance vis-à-vis the agency's Organizational Vision, Mission and Strategic Goals. It is a technology composed of strategies, methods, and tools for ensuring fulfillment of the functions of the offices and its personnel as well as for assessing the quality, quantity and timeliness of the accomplishments. Objective is an instrumental means to arrive where management wants to organization to go or a specific target to achieve [5].

Personal and professional characteristics of every employee in each agency vary accordingly. Employee's performance has contributed to or hindered organizational effectiveness. Role is a set of expectations from a person's behavior. Role is the expected behavior from a person based on his/her demographic profile [6].

\section{Responses of the Department Heads}

The responses of the department heads on professional competence, supervisory competence, leadership skills, personal qualities and public relations and community involvement. The identified typological categories are distributed into the specific indicators provided as to Professional Competence indicates that knowledge of educational policies, goals, objectives and thrusts knowledge of teaching methods and approaches; planning and organizing ability; communication skills; problem analysis and decision making; professional growth; and potentials for higher responsibilities have a remarks of Complied.

Supervisory Competence as to ability to formulate and implement supervisory plans; ability to plan, initiate and pursue his fractional enrichment activities; ability to identify needs and problems in his department and to act accordingly; ability to assist the subordinates to improve their competencies; ability to monitor, evaluate and keep record of subordinates' activities and performances; promptness in submission of reports and actual accomplishments in the improvement of instruction and other areas of concern have a remarks of Complied.
Leadership Skills as to skills in motivating and inspiring subordinates; perceptual capacity to evaluate subordinates' needs, attitudes and maturity level and to apply appropriate leader action and rapport with subordinates have a remarks of Complied.

Personal Qualities as to initiative, resourcefulness and dedication to service; frustration and stress tolerance; human relations; and manifestation of positive values have a remarks of Complied.

Source: Adapted from CTU-HR Form 8, October 2012, revision 1

This implied that that all the indicators for professional competence, supervisory competence, leadership skills, personal qualities and public relations and community involvement of the different department heads are satisfactorily complied. It can be deduced from the result that all the department heads of the College of Arts \& Sciences are highly competent and knowledgeable on the duties inherent to their functions and exudes salutary dedication to service and rapport to the subordinates. As stated by Nel, Welner, Haasbroek, Poisat, Sono, \& Schults [7]. Performance appraisal is a holistic approach and process towards the effective management of individuals and groups to ensure that their shared goals and institutional objectives are achieved. The process of determining how the management system will achieve its objectives. It determines how the organization can get where it wants to go. It is the systematic of development of action programs aimed at reaching agreed by the process of analyzing, evaluating and identifying opportunities which are foreseen [8].

\section{Responses of the Faculty}

The responses of the faculty on the typological category of teaching competencies, professionalism, and service to the university and community. Teaching competence and professionalism of the faculty plays an important role in carrying out the expected output to the clients. It includes knowledge of the subject matter, methodologies and techniques used, materials utilized for instruction, classroom management, communication skills, etc. while, professionalism speaks of its personal characteristic, professional growth, leadership and human relations.

Typological category as to Teaching Competencies with the following indicators knowledge of subject matter; teaching methodologies and techniques; preparation of curricular material and utilization for instruction; classroom management; communication skills; student achievement evaluation skill; time utilization and teaching effectiveness have remarks of Complied.

Professionalism as to attendance and punctuality, professional growth; leadership competence; manifestation of positive social or 
moral values; personal characteristics and human relation with the supervisors, peers and students have remarks of Complied.

Service to the University and Community as to participation in curricular and co-curricular services and others; involvement in research, extension services and other activities for advancement of the university and participation in community activities have remarks of Complied.

Source: Adapted from CTU-HR Form 7, October 2012, revision 0

Faculty of the College of Arts and Sciences have complied all the stipulated indicators for teaching competence, professionalism and service to the university and community. The result implies that all CAS faculty are proficient and dedicated in carrying - out the tasks assigned to them. According to Van der Waldt [9], it is usually difficult to measure performance improvement and productivity in the public service because the outputs are also intangible.

However, the necessary element of the Performance Appraisal Report entails performance improvement and productivity to ensure effective and efficient public service delivery.

\section{Responses of the Students}

Responses of the students on management and performance of teachers in delivering their duties to the clienteles. Management, being a function that coordinates the efforts of people to accomplish goals and objectives using available resources efficiently and effectively, should be in accordance with the indicators mentioned in the table below.

Management entails gives reasonable course/ subjects assignments; earns appreciation and kind attention from the students; gives orientation about the subject and how the students are evaluated; gives test and / or projects which are within the objectives of the course; shows concern in assisting the students; shows sympathetic insight into students' feelings; check and records test paper/term papers promptly; is on time and regular meeting the class; assigns fair subjects/course requirements and sustains the attention of the class for the whole period have a remarks of Complied.

Performance stated that presented lesson clearly, methodically, and substantially; motivates the students to learn; facilitates learning with the application of appropriate educational methods and techniques; shows mastery of the lesson; is prepared for the class; inspires students' self -reliance in their quest of knowledge; knows when the students have difficulty understanding the lesson and find ways to make it easy; integrates values into the lesson; speaks the language of instruction (English or Filipino) clearly and fluently; and delivers thought provoking questions have a remarks of Complied.

Source: Adapted from CTU-Students' Assessment Survey for Teachers

Majority of the students presented a positive response on all of the indicators given in terms of management and performance rendered to them. The students responded complied on all the performance indicators under management as to gives reasonable course/ subjects assignments, earns appreciation and kind attention from the students, gives orientation about the subject and how the students are evaluated,gives test and / or projects which are within the objectives of the course etc. On the same manner, the students responded complied on the performance of the teachers in terms of presenting the lesson clearly, methodically, and substantially, motivating the students to learn, facilitating learning with the application of appropriate educational methods and techniques, showing mastery of the lesson, integrating values into the lesson. It simply implies that the students learned more are satisfied on the performance of the teachers and the delivery of service.

Performance assessments assist by the clientile because they receive regular feedback on employee performance, Ivancevich et al. [10]. Performance assessments are normally done on a quarterly basis and also at the end of the fiscal year (annually).

\section{CONCLUSION}

Based on the findings of the study, success indicators of the Performance Appraisal for the Academic Year 2010-2012, the Cebu Technological University-Main Campus Particularly College of Arts and Sciences, Very Satisfactorily Complied for the variables indicated.

\section{ACKNOWLEDGEMENTS}

The authors would like to thanks the College of Arts and Sciences for extending their expertise and continuous support in the materialization of this undertaking.

The Research and Development Council of the university, for the support and encouragement. 
\begin{tabular}{l|lrl|l|ll} 
& ISRA (India) & $=\mathbf{1 . 3 4 4}$ & SIS (USA) & $=\mathbf{0 . 9 1 2}$ & ICV (Poland) & $=\mathbf{6 . 6 3 0}$ \\
Impact Factor: & ISI (Dubai, UAE) $=\mathbf{0 . 8 2 9}$ & PUHIL (Russia) $=\mathbf{0 . 1 7 9}$ & PIF (India) & $=\mathbf{1 . 9 4 0}$ \\
& GIF (Australia) & $\mathbf{0 . 5 6 4}$ & ESJI (KZ) & $=\mathbf{1 . 0 4 2}$ & & \\
\hline JIF & $=\mathbf{1 . 5 0 0}$ & SJIF (Morocco) $=\mathbf{2 . 0 3 1}$ & & \\
\hline
\end{tabular}

References:

1. Atiomo AC (2000) Practical Human Resources Management: Lagos Nigeria.

2. Victoria Valeriano (2016) CIVIL SERVICE COMMISSION'S PERFORMANCE MANAGEMENT SYSTEM. Available: http://unpan1.un.org/intradoc/groups/public/doc uments/EROPA/UNPAN027467.pdf (Accessed: 10.02.2016).

3. Drucker Peter F (2001) Management Challenges for the $21^{\text {st }}$ Century. New York: HarperCollinsPublishers, p.39.

4. Daft Richard L (2000) Management. (N.Y.: The Dryden Press, $5^{\text {th }}$ Edition 2000, p.7).

5. Santos Emmanuel (2005) Practice, Concepts, and Principles of Management. IAME Design Studio. Makati City.
6. Drucker Peter F (1974) Mangement: Taskd, Responsibilities and Practices. New York: Harper \& Row, Publishers.

7. Nel PS, Welner A, Haasbroek GD, Poisat P, Sono T, Schults HB (2008) Human Resource Management. Cape Town: Oxford University Press.

8. Certo, \& Jones, Harry (1974) Preparing Company Plans: A workbook for Effective Planning. New York: Wiley.

9. Van der Waldt G (2004) Managing performance in the public sector: Concepts, Considerations and Challenges. Lansdowne: Juta.

10. Ivancevich JM, Konopaske R, Matteson MT (2011) Organisational behavior and Management. New York: McGraw-Hill. 